\title{
Tax Evasion as a Crime: A Survey of Perception in Yemen
}

\author{
Khaled Slamen Yaslam Aljaaidi (Corresponsing author) \\ College of Business, Universiti Utara Malaysia \\ 06010 Sintok, Kedah, Malaysia \\ Tel: 60-175-068-841_E-mail: aljaydi_khaled@yahoo.com \\ Dr. Nor Aziah Abdul Manaf \\ College of Business, Universiti Utara Malaysia \\ 06010 Sintok, Kedah, Malaysia \\ Tel: 60-124-166-469Ｅ-mail: aziah960@uum.edu.my \\ Professor Stewart S. Karlinsky \\ College of Business, Area of Accounting and Finance \\ One Washington Square, San Jose, CA 95192-0066, USA \\ Tel: 1-408-924-3482 E-mail: Karlin_s@cob.sjsu.edu
}

Received: February 21, 2011 Accepted: May 20,2011 doi:10.5539/ijbm.v6n9p190

\begin{abstract}
This paper explores the perception of Yemeni citizens of the severity of tax evasion relative to other crimes and violations. Perception of tax evasion may somewhat explain the degree of non-compliance with the tax laws. Using data from a self- administered survey and a personnel structured interview, the results of mean and comparative analysis show that tax evasion items were ranked as the three least crimes of 30 listed crimes. Further, Tax evasion is categorized the least serious category out of six categories. The results of this study should be useful to policy makers in Yemen and elsewhere, as it was found that there is an alarming signal that tax evasion is relatively ranked as the least serious offence, which could lead to an environment where taxpayers may not be afraid of cheating on their tax returns.
\end{abstract}

Keywords: Tax evasion as a crime, Other offences, Yemen

\section{Introduction}

Albeit Yemen has introduced the self-assessment system ('SAS') in 2004 to be applicable to all taxpayers (Aljamaree \& Algaylee, 2007), established a specific public administration for combating tax evasion, and carried out several international, regional, and governmental efforts to minimize financial crime, tax evasion, the level of tax evasion still remains questionable (Embassy of Yemen, 2007). Specifically, previous studies have evidenced that the voluntary compliance behavior of taxpayers is derived from the fully implementation of selfassessment system. As a result, tax authorities bear low cost of collecting taxes through the voluntary compliance (Brand, 1996). But the tax non-compliance found to be existed everywhere and the tax authorities are working hardly to reduce the tax non-compliance and maximize the voluntary compliance rates (Hasseldine, 1999; Pentland \& Carlile, 1996).

This problem of the tax non-compliance has led to an environment that motivates the Yemeni taxpayers not to report andlor pay their taxable income (Embassy of Yemen, 2007). Studies, conducted about the perceptions of tax evasion as a crime, have suggested that the tax non-compliance environment has been created from the perception of the taxpayers towards tax evasion as a non- serious crime (Karlinsky, 2004; Abdul Manaf \& Abdul Jabbar, 2006). Consequently, the degree of non-compliance with the tax laws could be explained somewhat by the perception towards the tax evasion. And, it is obvious that the public's perception of the severity of a crime has important implications for society (Karlinsky et al., 2004). However, those studies are inconclusive in explaining the variability of the perceptions towards tax evasion as a crime. Despite that fact that these researches conducted on this area in US, Australia, and Malaysia are a few, a study about the perception of tax evasion in Yemen does not exist. Evidence on tax evasion perception found in the Western and other developing countries may not be generalized to the context of Yemen because of the differences in the environmental factors 
such as economy, business, culture, and regulations. Consequently, differences in the environmental factors are expected to cause differences in the perception.

The Islamic religious perspective that has not been explored yet is believed to influence the perceptions of the Yemeni citizens towards tax evasion has been investigated using the personnel structured interview method. The previous studies conducted to measure the Islamic religious perspective, concluded that Muslims are more flexible in their perceptions towards the topic of tax evasion (McGee, 1998b; Murtuza \& Ghazanfar, 1998). Thus, this study measures the perceptions of Yemenis towards the severity of tax evasion as a crime relative to other offences.

\section{Literature Review}

\subsection{Crime and Tax Evasion in Yemen}

The Yemeni Penal and Code Law No. (12), (1994) classifies crime into two types: serious crimes and non-serious crimes. Serious crimes refer to the crimes punished by executing, cutting off one organ or more than one, andlor imprisoning for more than three years. Non-serious crimes refer to the crimes punished by fining andlor imprisoning for less than three years. It is believed that people would classify non-serious crimes as less serious than serious crimes. Examples of each type of crime are given in Table 1 below (Yemeni Interior Ministry, 1994).

It is important to differentiate between crimes involve people and crimes do not. It is evidenced that people view crimes that do not involve people as less serious than those involve people (Karlinsky et al., 2004). As it is stated that a violation is an offence because it is usually punishable by a fine only compared to crime. This is often punishable with imprisonment (Warr, 1989). The majority of the offences in the Yemeni Penal and Code Law No (12), (1994) are punished with imprisonment. Accordingly, the appropriate categorization to the context of Yemen is classifying crimes based on their seriousness and victim and victimless and they are categorized into serious crimes and non-serious crimes. Examples of the classifications of serious and non-serious crimes as victim and victimless are provided in the table 2 below.

Even more, the crimes can be divided into six groups based on their types. These include drug related crimes, violent crimes, commercial crimes, property crimes, traffic offences and other crimes as it is shown in the table 3.

Furthermore, the recent data available about the crimes and judiciary statistics indicators are the ones highlighted for 2003-2004 by the Central Statistics Organization in Yemen as shown in table 3 below (Central Statistical Organization, 2003-2

Importantly, in the international rank, Yemen is considered the least country regarding crime rate. It is highlighted as 1.16109 crimes per 1000 people (Yemeni Crime Statistics, 2008).

Indeed, in Yemen, tax evasion does not form part of the crimes under the jurisdiction of the security and police administration, Interior Ministry. Tax evasion and any other direct tax-related issues are under the administration of the Yemeni Tax Authority, Yemeni Finance Ministry.

The Yemeni Income Tax Act No.12 for the year 1999 has enacted various penalties, fines and periods of imprisonment for non-compliance, of which one is directly related to 'tax evasion' as provided in chapter 7, article (90). Willful evasion under this code refers to any one or all of the following offences:

a) Submitting an incorrect declaration by omitting, reducing or deleting any income or part of it, which was supposed to have been declared in accordance with the provisions of this Law, and as such affects the amount of tax.

b) Introducing any false statement, submitting a false entry or incorrect statements in any of the documents or statements submitted in accordance with this Law.

c) Preparing, maintaining, or permitting any forged books, accounts, or false entries to be prepared and maintained, or allowing such books, accounts or entries to be faked, concealed or damaged, wholly or partially, with the intent to hide or exclude any income subject to tax under this Law, or any part thereof, with the intent to avoid payment of tax, wholly or partially, or attempting to obtain an unlawful exemption.

d) Resorting to any fraudulent method, whatever it may be, or allowing the use of the same to avoid payment of tax or reduce its amount by any means.

e) Delivering any incorrect information or statements with regard to any matter or incident that may affect his or any other person's responsibility towards payment of tax, or result in the reduction of its amount.

f) Delivering any false written reply to a question or a request addressed to him for obtaining information or particulars required under this Law, with the intent to avoid payment of tax, wholly or partially.

On being convicted, the offender shall be punished for any of the above offenses by imprisonment for a term of not less than one month and not more than one year, or by payment of a fine not less than $50 \%$ and not more that $150 \%$ of the benefit derived as a result of committing such an offense or violation. The punishment shall be doubled in case the same offense or violation is committed twice or repeated (Yemeni Tax Authority, 1999). 
The six items of offences that are considered an action of tax evasion can be categorized into three main broad activities. These include understatement of taxable income, overstatement of tax deductions and fail to submit a tax return.

As it is known in the literature review that tax evasion is very difficult to be measured. Schneider and Enste $(1998,2002)$ have utilized a variety of methods in an attempt to estimate the size of the "shadow economy" which may be expected to be highly correlated with overall tax evasion while Others have resorted to experimental methods to examine the factors that determine why people pay taxes (Lewis, 1982; Pommerehne et al., 1994; Frey, 1997, 2003; Alm et al., 1992, 1999; Frey and Feld, 2002; Feld and Tyran, 2002; Torgler, 2002). Still others have examined a concept that is, in some sense, a prior notion for tax evasion: "tax morale". In the case of Yemen, Detailed data are not available about the number of cases of tax evasion in Yemen. The only information available is that The Yemeni tax authority has estimated the tax gap is \$164 Million annually (Yemen Times, 2005). Thus, Yemen would experience the situation found by the study of Peacock and Shaw (1982) that revealed an increase in tax evasion will result in an expansion of domestic income and contraction in the Government's tax revenue if the marginal propensity to spend out of tax evaded is less than unity. Clotfelter (1983) evidenced that successful tax evasion has serious consequences to Governments as it not only cause losses in current revenues but it fosters a threat to voluntary compliance.

\subsection{Islamic Perspectives towards Tax}

There is a lack of research about the influence of Islamic religious perspectives on tax evasion. Generally, few studies conducted about the tax system to be implemented as a national revenue collection system in Islamic countries focused on imposing Zakat instead of the tax. Peerzade (2005) proposed two conditions in the tax system to be considered as an Islamic tax system. The first condition is necessary in which the perceived approach of Zakat should form the core of the resource mobilization effort. The second condition is that, in addition to the current secular rules and regulations regarding rates, exemption levels, administration, etc., the approach should also incorporate the Islamic prescriptions. Murtuza and Ghazanfer (1998) examined the religious literature and reported that Muslims have a duty to God to contribute to the poor. They have not indicated to the relationship between the individual and the government.

Raquibuz Zaman (1986) indicated that it is an ethical behavior for a Muslim to evade indirect taxes which include excise taxes, customs duties and perhaps corporate income taxes. Additionally, he clarified that Muslims do not have to pay tax, particularly the taxes which lead to the increase in the consumer prices. Furthermore, it is unjust when the Islamic perspective forbade the evasion of taxes, while Non-Muslim residents would evade the taxes, and enjoy all the tax benefits. Al-Awwal (2005) has reported that every taxpayer has a right to arrange its affair in a manner to minimize the tax incident within the ambit of the provisions of tax laws. If the arrangement is such that it is contrary to, the provisions of law, it amounts to evasion of tax, which is an offence. Under tax planning, what is required to be done is that the taxpayer should avail the benefit of all the deductions, exemptions properly to minimize the incidents of tax as provided in the statute. Consultancy on tax planning is an important business in many advanced countries. Further, In 1997 and 1998 there were other surveys conducted who found that the tax evasion may be justified if the tax will increase the prices or when the tax are imposed on the income.

Nevertheless, some Islamic thinkers believe that the Muslim has to pay tax, and justified their opinion by two reasons: firstly, that tax is paid for services provided and to facilitate many transactions related to taxpayer's life and trade. Secondly, that Muslims should pay what is required because evasion of taxes may lead to the evasion of Zakat (Islamic Economic Program, 2009).

There are three main perspectives towards paying taxes by Muslims. (1). the first group (The first Islamic perspective (Collecting the tax by Governments is completely prohibited in all cases. We, as Muslims, have been already given a perfect system, Zakat, to do so from Allah, the God, has been ruled in the Holy Quran and the Prophet Mohammad (Peace and blessing of Allah be upon him) has taught us how to implement this system. So it is forbidden to import non- Muslim, Western, tax system and replace it with the Islamic Zakat system. (2) The second group (the second Islamic perspective): This group agrees with the first group about the prohibition of collecting tax in Islamic countries generally except that there are some conditions the Government has the right to impose tax and, in this case, it is not considered a sin. These conditions are as follows:

- There is a legitimacy public need of the money.

- Inadequate Islamic legitimacy resources: Kalzkah, Sayyid Qutb, abscess, Ushur.

- Eliminate wasteful expenditure before imposing tax.

- Consulting Islamic parliament before implementing tax.

- The tax imposed should be amounts as needed.

- It should be imposed justly and according to legitimacy Islamic resources.

- The tax collected has to be spent in the interests of the nation for which it was collected. 
2.3 The third group (The third Islamic perspective): This group argues that Muslims under an Islamic government have to obey the rules and laws of the government (Verdict Encyclopedia, 2010).

\section{Research Design and Methodology}

\subsection{Theoretical Framework}

Tax researchers have investigated why some people pay taxes while others do not. Through experiments (Boylan and Sprinkle, 2001), random surveys (Fisher et al., 1989), and available tax databases (Erard and Ho 2001), researchers have identified characteristics of noncompliant taxpayers and what is likely to motivate tax compliance. Specifically, studies conducted about the tax evasion considered this practice as a 'white-collar crime' or a type of criminal behavior (Wentworth \& Rickel, 1985; Jackson \& Milliron, 1986; Ghosh \& Crain, 1995).

In such case, it is evidenced that tax non-compliance has led to an environment where Yemeni taxpayers have been motivated not to report andlor pay their taxable income (Embassy of Yemen, 2007). Several studies, conducted about the perceptions of tax evasion as a crime, have suggested that the tax non-compliance environment has been created from the perception of the taxpayers towards tax evasion as a non- serious crime (Karlinsky, 2004; Abdul Manaf \& Abdul Jabbar, 2006). Consequently, the degree of non-compliance with the tax laws could be explained somewhat by the perception towards the tax evasion. And it is obvious that the public's perception of the severity of a crime has important implications for society (Karlinsky, 2004). It will result an expansion of domestic income and contraction in the Government's tax revenue if the marginal propensity to spend out of tax evaded is less than unity. Clotfelter (1983) evidenced that successful tax evasion has serious consequences to Governments as it not only cause losses in current revenues but it fosters a threat to voluntary compliance.

This research tries to investigate the level of seriousness of tax evasion compared to other offences. A comparison will be made among the rank of each crime and violation given by the respondents as a high or low rank crime or violation. Further, the tax evasion crime rank will be identified among the list of the offences to determine the level of the seriousness of this crime compared to other offences.

\subsection{Hypotheses Development}

\subsubsection{The level of seriousness of tax evasion compared to other offences}

The level of seriousness of tax evasion compared to other crimes and violation has been evidenced, previously, by a few numbers of studies (Karlinsky et al., 2004; Abdul Manaf \& Abdul Jabar, 2006; 2001; Warr, 1989). The results indicated by those studies that there is a significant difference in the perceptions of tax evasion compared with violent crimes, drug related crimes and traffic offences. The results suggest that people do not perceive tax evasion to be as serious as violent crime and drug related crimes. Thus, the following hypothesis is developed to be tested by the current study:

$\mathrm{H}_{1}$ : Tax evasion is perceived a less serious crime compared to other offences.

\subsection{Data Collection}

\subsubsection{Sample Selection}

As for the sample to be chosen for distributing out the questionnaire, the disproportionate stratified sampling is applied to select sample subjects that represent the most suitable ones in providing data about the dimensions of the study. This method is been chosen in order to choose the right sample to represent the whole population.

A sample of 400 Yemeni individuals was selected for the current study to obtain data from using the disproportionate stratified random sampling. These individuals are the most suitable people to provide data about the dimensions of the study. Under simple random sampling, all elements in the population are considered and each element has an equal chance of being chosen as the subject. The sample subjects include individuals working for private and governmental sectors, businessmen, students, jobless and self-employed individuals. The questionnaires returned were 310 questionnaires that represent $77.5 \%$ response rate. Twenty percent of the sample was female.

\subsubsection{Procedures}

In the current study, data are obtained from primary and secondary sources. Regarding obtaining data from the primary sources, in this research, two appropriate data collection methods are used. This includes: (1) a survey; (2) a personal structured interview as the following.

\subsubsection{A survey Method}

Using this method of data collection, Yemeni individuals were asked to fill in the self-administered questionnaire. This questionnaire is adopted and adapted from the previous studies conducted to measure the perceptions toward tax evasion as a crime (Karlinsky et al., 2004; Abudl Manaf and Abdul Jabbar, 2006). A survey is chosen because it involves surveying people and recording their responses for analysis. The strength of the survey as a primary data collecting approach is that it does not require a visual or other objective perception of the information sought (Cohen, 1988). 
The questionnaire is divided into two sections. Section A consisted of three parts relating to rating the severity of crimes. The first part (questions 1 to 30) measured opinions on 30 offences. The respondents are asked to indicate their agreement on all items using a five-point Likert scale. (1 as not serious to 5 as extremely serious).

Question 31 to 32, in Section A, deal with ranking of the top five most serious offences as well as the top five least serious offences. The respondents need to provide ranking based on the offences identified from questions 1 to 30 .

Section B of the questionnaire is designed to obtain demographic characteristics of the respondents. Questions asked in this part relate to age, gender, marital status, education, source of income, and level of income.

One major contribution in the methodology of this study is by breaking the general 'tax evasion' item into three specific types of tax evasion behavior (Baldry and Kasipillai, 1996). These specific tax evasion behavior items refer to understatement of income, overstatement of deductions and failure to submit a tax return. Prior similar studies have focused on 'tax evasion or 'tax fraud' or both as a general item only (Karlinsky et al., 2004).

Originally, the listing of 30 offences in the questionnaire was organized randomly without stating the category of offences. The reason is to ensure that respondents fully and carefully read the questions before answering. Finally, to ensure gaining high respond rate, the questionnaires were personally distributed out to the individuals.

3.3.2.2 A personal structured interview

Using this method of data collection, two predetermined questions were asked personally to the respondents. The questions were as the following. (a) How do you perceive tax evasion as a crime? (b) Are Muslims obliged to obey the Islamic leader to pay tax?

Thirty individuals were interviewed personally. As the respondents expressed their views, the researcher noted them down. The same questions were asked to everybody in the same manner.

The main purpose of the interview was to support the results would be measured by the survey instrument and to investigate the Islamic religious perceptive towards tax evasion in a way that this factor might influence the level of individuals' perceptions in the seriousness of tax evasion as a crime.

Regarding obtaining data from the secondary sources, in this study, data would be retrieved from the existing sources such as the governmental websites, articles, magazines, internet, newspaper, governmental publications, journals, doctoral dissertations as well as master theses. While seeking for secondary data, time and costs of acquiring information would be saved (Sekaran, 2003; Zikmund, 2003).

\section{Results}

\subsection{Profile of Respondents}

As indicated earlier, a total of 335 questionnaires were gathered from the survey. As shown in Table 5, the majority of the respondents $(78.2 \%)$ were male, and $21.8 \%$ were female. The largest group $(62.4 \%)$, in terms of age, was those aged between 30 and 49 . Specifically, $27.2 \%$ were aged between 18 and 29 , while $10.4 \%$ were aged between 50 and above. In terms of marital status, the majority of the respondents (73.4\%) were married, $23 \%$ was single, and 3.6\% was either divorced or widowed. Regarding the level of education, the largest group $(41.8 \%)$ was a bachelor degree holders, $21.2 \%$ was a high school certificate holders, $19.4 \%$ was a diploma degree, after high school and before a bachelor degree, holders, 14\% was a pre-high school certificate holders, and $3.6 \%$ was master and $\mathrm{PhD}$ degree holders.

In terms of the occupation and source of income, the majority of the respondents $(56.1 \%)$ were governmental sector employees receiving their income from the government, $25.7 \%$ was private sector employees receiving their income from the private source of income, $7.2 \%$ was businessmen and self-employed individuals receiving their income from their own business, and the remaining of the respondents $11 \%$ were working for other types of employers and receiving their income from them. As for their level of income, equally $40.3 \%$ of the respondents were receiving an annually salary ranging from Y.R240001 to 500000, 33.4\% was receiving Y.R240000 and below annually, $17.3 \%$ was receiving from 500001 to 1000000 annually, $5.4 \%$ was receiving 5000001 and above annually, and $3.6 \%$ was receiving from 1000001 to 2000000 annually. It is found that a large majority of the respondents $(65.1 \%)$ were preparing their tax return by others such as their employer, $20.3 \%$ was prepared by tax agent, $9.3 \%$ was assisted by a friend or relative, and the remaining $(5.4 \%)$ of the respondents were preparing their own tax return.

\subsection{Perceptions towards Tax Evasion Compared to Other Offences}

The objective the current study tries to investigate is measuring the level of seriousness of tax evasion compared to other offences. This section highlights perceived differences in perception of tax evasion offences compared to other offences. Table 6 highlights the Mean Scores and Rank of the 30 offences examined under this study.

As it is shown in Table6 that the most five serious crimes are Islamic abuse, murder, drug traffickingldealing, adultery and prostitution. On the other side, the least serious offences are ranked as fail to submit a tax return, overstatement of tax deductions, understatement of taxable income, begging and fireworks acquiring $\backslash d$ dealing. It is obvious that the three items related to tax evasion are ranked $28^{\text {th }}, 29^{\text {th }}$ and $30^{\text {th }}$ offences. The reasons that 
make Yemenis perceive Islamic abuse as the most serious crime is a religious and cultural factors. Yemen is a Muslim country regulating Islam as the source of its laws and codes. In Islam, the biggest sin is abusing any Islamic sign. Further, murder in Islam is considered one of the more severe sins.

Also, even drug related crimes are victimless, as mentioned earlier, they are considered as severe because of their implications and consequences, including the potential of leading to other violent crimes. Furthermore, the culture in Yemen goes close with the Islamic teachings in a way that Yemenis are more conservative people and they consider prostitution and adultery are among the biggest sins. Importantly, the results of the previous studies ranked the first five offences to be murder, rape and child molestation, drug trafficking and robbery with firearms and the least serious crimes as failure to submit a tax return, driving while using mobile phone, speeding, overstatement of tax deductions and understatement of taxable income (Abdul Manaf \& Abdul Jabbar, 2006).

In the study of Karlinsky et al., (2004), it was found that the first three offences were ranked as murder, rape and child molestation. In the Australian study, heroin trafficking is ranked as the second most serious offence (Wilson et al., 1986). While in Canada, three drugs related offences (high level of drug trafficking, drug importing and selling drugs on the street) are ranked amongst the top six most serious offences in 2000 and 2001. However, drug related offences are ranked lower $\left(12^{\text {th }}\right.$ and $14^{\text {th }}$ most serious offences) in 2003 and 2004 (Criminal Intelligence Service Alberta, 2005). It is important to note that drug offences have been reworded as 'drug importing, exporting and trafficking' and 'street-level drug trafficking' in 2003 and 2004 (Abdul Manaf \& Abdul Jabbar, 2006).

Further, the ranking is made in terms of category of crimes. There are six categories identified in this study. The results are depicted in Table 7.

It is important to note from Table 7 that tax evasion is sixth out of six categories of offences. The first rank is drug related crimes followed by violent crimes, other crimes, commercial crimes and property crimes. The rank of the first two categories, drug related crimes and violent crimes, goes in the same line with the previous study of Abdul Manaf and Abdul Jabbar (2006). Importantly, tax evasion category is ranked as the last rank of seriousness.

Prior studies in the US (Cabrera, 1999), the UK (Bennett, 2000), and Australia (Makkai et al., 2000) found that there is a relationship between drug abuse and involvement in criminal activities. Consistent with those, a study on drug addicts with and without criminal history, in Penang, Malaysia, confirms that there is a positive relationship between drug abuse and involvement in criminal offences (Karofi, 2005).

The category of tax evasion is also compared with other category of crimes and offences (5 items) and the summary of paired t-test results are shown in Table 8.

The results indicate significant differences in perceptions of seriousness of tax evasion compared with drug related crimes, violent crimes, property crimes, other crimes and commercial crimes. People do not perceive tax evasion to be as serious as violent, drug related, property, other crimes and commercial crimes. In other words, tax evasion as a crime is the least perceived offence related to the other groups of crimes. This result is in the line with the previous study of Abdul Manaf and Abdul Jabbar (2006) and Karlinsky et al., (2004) who suggest that tax evasion is less likely to be perceived as violent, drug related and commercial crimes.

The results indicate that tax evasion related items are ranked $28^{\text {th }}, 29^{\text {th }}$ and $30^{\text {th }}$ out of 30 offences. The general trend of perceptions seems to be similar and consistent with the previous studies (Karlinsky et al., 2004; Abdual Manaf and Abdul Jabbar, 2006). However, this study shows tax evasion relatively ranked the least serious offences. This means that people in Yemen perceive tax evasion as a non-serious crime compared to the other crimes and offences. This fact leads to an environment where Yemenis practice tax evasion as an ordinary behavior.

From Table6, 4.3 and 4.4, it appears that people in Yemen are less likely to perceive tax evasion as a serious crime related to other crimes and offences. Thus, hypothesis $\mathrm{H}_{1}$, Tax evasion is perceived a less serious crime compared to other offences, is accepted.

\section{Discussions and Conclusions}

\subsection{Discussion}

This study measures the perceptions of Yemeni citizens as to the severity of tax evasion relative to other offences. As it is stated earlier that one major contribution of this study is the introduction of three specific types of tax evasion behavior in Yemen. Largely, this survey utilizes insights of a questionnaire used in previous studies with some modifications to suit the context of Yemen.

Based on the research findings presented in Section Four, the perception of Yemeni citizens towards tax evasion as a crime is reported based on the following: a comparison has been made to measure the Yemeni citizens' perceptions towards tax evasion and other 30 offences. The analysis of Mean Scores was performed to the 30 crimes and to the category of crimes to rank the score of tax evasion compared to the other offences and the paired t-test was applied to compare the category of tax evasion with other category of offences as stated earlier 
in Section Four. The results of the performed analysis indicate that Yemeni citizens perceive tax evasion as the least serious crime compared to the other given offences and there is a difference between the category of tax evasion as a crime and the other categories of crimes in terms of their severity. The tax evasion three items were ranked as $28^{\text {th }}, 29^{\text {th }}$ and $30^{\text {th }}$ out of 30 crimes and the tax evasion category was ranked as the least score of Mean equaled 2.17 out 5 likert point scale. Accordingly, hypothesis $\mathrm{H}_{1}$, which is developed as tax evasion is perceived a less serious crime compared to other offences, is accepted.

Furthermore, from the interviews conducted, it seems that respondents perceive tax evasion as the least serious crime. This perception is influenced by the Islamic perceptions towards collecting taxes. It appears that the majority of respondents agree with the fist two Islamic perspectives towards collecting taxes (see section 2.2).

\subsection{Conclusion}

Theoretically, this study reasonably has achieved its objective to measure the perceptions of Yemeni citizens as to the severity of tax evasion relative to other offences.

The objective of the study has been achieved through the result after conducting the analysis of Mean Scores and paired T-test. This objective deals with whether there is a significant difference in the perception of the seriousness of tax evasion compared to the given 27 offences. The results highlight that tax evasion related items are ranked $28^{\text {th }}, 29^{\text {th }}$ and $30^{\text {th }}$ out of 30 offences. The general trend of perceptions seems to be similar and consistent with the previous studies of Karlinsky et al., (2004) and Abdual Manaf and Abdul Jabbar (2006). However, this study shows that tax evasion is ranked the least serious crime compared to the other 27 given offences $\left(28^{\text {th }}, 29^{\text {th }}\right.$ and $30^{\text {th }}$ out of 30 offences).

As for the other categories, tax evasion category ( 3 tax evasion items) is ranked sixth (out of six categories). It was indicated that tax evasion as a category of offences is found to be the least serious than the other five categories of offences. Comparison of tax evasion (as a category) with other categories of crimes (6 categories) revealed that significant differences exist in perceptions of the seriousness of tax evasion with all offences categories.

As for the interviews conducted, it appears that there is an obvious influence of the Islamic perspectives on the perceptions of Yemeni people towards tax evasion. The majority of respondents believe that either collecting taxes by Governments is completely prohibited in all cases or collecting taxes is permitted only in some cases as stated in section 2.2.

This study is still subject to some limitations. One of the limitations of this study is that this paper has reported 310 respondents' opinion towards tax evasion. Thus, the results have not shown a whole picture of all people in Yemen. Future research is required to extend the results of this research and fill in this gap. The second limitation of this study is that the time considered under investigation is limited to perception of people in 2008 . Hence, future research is required to extend the results of this study by covering a range of previous years to this study and/or post-periods to this study. Finally, this study has explored the perception of Yemeni people towards tax evasion using questionnaires and interviews. Therefore, the results found in this study are limited to the methodological approach used. Future research is required to extend and confirm these results by using different methodological approaches and introducing several variables such as the country-specific factors: religion, culture, political system, economic development.

\section{References}

Abdul Manaf, N., \& Abdul Jabbar, H. (2006). A Survey of Perception Towards Tax Evasion As A Crime. Further Global Challenges in Tax Administration. Fiscal Publications.

Al-Awwal, R. (2005). Tax Planning from an Islamic Perspective. [Online] Available: http://islamiccenter.kaau.edu.sa/english/Forum/Islahi_01.pdf

Aljamaree, Y., \& Algaylee, A. (2007). Financial Ministry Implements Transparency Principle to Reform the financial regulations and Laws. [Online] Available: http://www.sabanews.net/ar/news131480.htm (June 10, 2008)

Alm, J., B. Jackson, and M. McKee. (1992). Estimating the Determinants of Taxpayer Compliance with Experimental Data. National Tax Journal, 45 (1), pp. 107-14.

Alm, J., McClelland, G.H., and Schulze, W.D. (1999). Changing the social norm of tax compliance by Voting. KYKLOS, 48 (1), pp. 41-171.

Bennett, T. (2000). Drugs and Crime: The Results of the Second Development of the New ADAM Programs Home Office Study.

Boylan, S., and G. Sprinkle. (2001). Experimental Evidence on the Relation between Tax Rates and Compliance: The Effect of Earned vs. Endowed Income. Journal of the American Taxation Association, 23 (1), pp. 75-90.

Brand, P. (1996). Compliance: A $21^{\text {st }}$ Century Approach. National Tax Journal, 49 (3), pp. 413-420.

Cabrera, S. (1999). Drug Use among Hispanic Youth: Examining Common and Unique Contributing Factors. Hispanic Journal of Behavioral Sciences, 2 (1). 
Central Statistical Organization. (2003-2004). Crimes and Judiciary Statistics Indicators for 2003-2004. [Online] Available: http://www.cso-yemen.org/content.php?lng=english\&id=310. (July 3, 2008)

Clotfelter, Charles T. (1983). Tax Evasion and Tax Rates: An Analysis of Individual Return. Review of Economics and Statistics, 65(3), pp. 363-73.

Cohen, J. (1988). Statical Power Analysis for the Behavioral Science. Hillsdale, New Jersey: Lawrence Erlbaum. Criminal Intelligence Service Alberta, Provincial Public Opinion Survey on Organized Crime (2001) and (2004). (2005). Criminal Intelligence Service Alberta. (November 10, 2005) [Online] Available: http://www.cisalberta.ca/surveys /2004 \%20public \%20opinion\%20survey.pdf

Embassy of Yemen. (2007). Structure and Features of the Yemeni Economy. (June 10, 2008) [Online] Available: http://www.yemenembassy.org/economic/YemeniEconomy.htm

Erard, B., and C. Ho. (2001). Searching for Ghosts: Who Are the Nonfilers and How Much Tax Do They Owe? Journal of Public Economics, 81, pp. 25-50.

Feld, L.P., and Tyran, J-R. (2002). Tax evasion and voting: an experimental analysis. KYKLOS, 55 (2), pp. 197-222.

Fisher, R., J. Goddeeris, and J. Young. (1989). Participantion in Tax Amnesties: The Individual Income Tax. National Tax Journal, 42 (2), pp. 15-27.

Frey, B.S. (1997). Not Just for the Money -An Economic Theory of Personal Motivation. Edward Elgar Publishing Limited, Cheltenham.

Frey, B.S., and Feld, L.P. (2002). Deterrence and morale in taxation: an empirical analysis. Working Paper No. 760, CES ifo, Munich.

Ghosh, D., \& Crain, T. (1995). Ethical Standards, Attitudes toward Risk, and International Non-compliance: An Experimental Investigation. Journal of Business Ethics, 14 (5), pp. 353-365.

Hasseldine, J. (1999). Gender Differences in Tax Compliance. Asia-Pacific Journal of Taxation, 3 (2), pp.73-89.

Islamic Economic Program. (2009). Al kharaj and Related Issues: A comparative Study of Early Islamic Scholarly Thoughts and Their Reception by Western Economists. [Online] Available: http://www.islamic-world.net/economics/al_kharaj.htm

Jackson, B., \& Milliron, V. (1986). Tax Compliance Research, Findings, Problems and Prospects. Journal of Accounting Literature 5, pp. 125-161.

Karlinsky, S., Burton, H., \& Blanthorne, C. (2004). Perceptions of Tax Evasion as a Crime. E-Journal of Tax Research, 2 (2), pp. 226-240.

Karofi, U. (2005). Drug Abuse and Criminal Behavior in Penange, Malaysia: A Multivariate Analaysis. Bangladesh e-Journal of Sociology, 2(2), 1-26. [Online] Available: http://www.bangladeshsociology.org/BEJS\%20-\%202.2\%20Karofi\%20-20Drug\%20abuse.pdf (December 7, 2005)

Lewis, A. (1982). The Psychology of Taxation. Martin Robertson Publishing Limited, Oxford.

Makkai, T., Fitzgerald, J., \& Doak, P. (2000). Drug Use among Police Detainees. Bulleting on Crime and Justice.

McGee, R. W. (1998b). The Ethics of Tax Evasion in Islam: A Comment. Journal of Accounting, Ethics \& Public Policy, 1, pp. 162-168.

McGee, R. W., \& Guo, Z. (2006). The Ethics of Tax Evasion: A Survey of Law, Business and Philosophy Students in China. Published in the Proceedings of the International Academy of Business and Public Administration Disciplines (IABPAD), 2006 Winter Conference, Orlando, Florida, January 3-6, pp. 748-763. Reprinted at www.ssrn.com.

McGee, R. W., \& Lingle, C. (2005). The Ethics of Tax Evasion: A Survey of Guatemalan Opinion. Presented at the 60th International Atlantic Economic Conference, New York, October 6-9, 2005. [Online] Available: www.ssrn.com.

McGee, R.W., \& Smith, S.R. (2006). Ethics, Tax Evasion and Religion: A Survey of Opinion of Members of the Church of Jesus Christ of Latter-Day Saints, Andreas School of Business Working Paper, Barry University.

Murtuza, A., and Ghazanfar, S. (1998). Taxation as a Form of Worship: Exploring the Nature of Zakat. Journal of Accounting, Ethics and Public Policy, vol. 1, No 3, 134-161.

Peacock, A., \& Shaw, G. (1982). Tax Evasion and Tax Revenue Loss. Public Finance, 37, pp. 268-278.

Peerzade, S. (2005). Towards Self-Enforcing Islamic Tax System: An Alternative to Current Approaches. J.KAU: Islamic Econ., Vol. 18, No. 1, pp. 3-12.

Pommerehne, W., Hart, A., and Frey, B.S. (1994). Tax morale, tax evasion and the choice of policy instruments in different political systems. Public Finance, 49, pp. 52-69. 
Raquibuz Zaman, M. (1986). Monetary and Fiscal Policies of an Islamic State. The American Journal of Islamic Social Sciences, vol. 3, No. 1, pp. 125140.

Torgler, Benno. (2002a). Does Culture Influence Tax Morale? Evidence from Different European Countries. WWZ (Wirtschaftswissenschaftlichen Zentrum der Universita"t Basel) Discussion Paper, 02/08.

Verdict Encyclopedia. (2010). Collecting Taxes: An Islamic Perspective. [Online] Available: http://www.islamweb.net/ver2/Fatwa/ShowFatwa.php?Option=FatwaId\&lang=A\&Id=26096

Warr, M. (1989). What is the Perceived Seriousness of Crimes? Criminology, 28, pp. 795-821.

Wentworth, D., \& Rickel, A. (1985). Determinants of Tax Evasion and Compliance. Behavioral Science \& the Law, 3 (4), pp. 455-466.

Wilson, P., Walker, J., \& Mukherjee, S. (1986). How the Public Sees Crime: An Australian Survey. Australian Institute of Criminology Trends and Issues in Crime and Criminal Justice.

Yemen Times. (2005). Auditing Body to Fight Corruption. Transparency International's Quarterly Newsletter. [Online] Available: transparency.org/content/download/2270/14250/version/1/file/ti_q_jun2005.pdf(July 12, 2008)

Yemeni Crime Statistics. (2008). [Online] Available: http://www.nationmaster.com/country/ym-yemen/cri-crime. (July 5, 2008)

Yemeni Interior Ministry. (1994). The Yemeni Penal and Crime Code No. (12). [Online] Available: http://www.police-info.gov.ye/Laws/Pun02.htm. (July 4, 2008)

Yemeni Tax Authority. (1991). The Income Tax Law (law No. -12- of 1999) (as amended). [Online] Available: http://www.tax.gov.ye/rules.php?address=5 (June 2, 2008)

Zikmund, W. (2003). Business Research Methods. Thomson, South-Western, Seventh Edition.

Table 1. Examples of Serious and Non-serious Crimes

\begin{tabular}{|l|l|}
\hline \multicolumn{1}{|c|}{ Serious Crimes } & \multicolumn{1}{|c|}{ Non-serious Crimes } \\
\hline Rape & Pick-pocketing \\
Bribery & Understatement of Taxable Income \\
Drug Trafficking Financial Fraud & Sexual Harassment \\
Murder & Overstatement of Tax Deductions \\
Terrorism & Employing Illegal Worker \\
Adultery & Prostitution \\
Homosexuality & Shop-lifting \\
Islamic Abuse & Fail to submit a Tax Return \\
Official Document Forgery & Illegal Gambling \\
Currency Forgery & Alcohol Drinkingldealing \\
Robbery with Firearms & Begging \\
Official Seal Forgery & Fireworks Acquiringldealing \\
Robbery without Firearms & Running a Red Light \\
Arson & Intentional Killing Peoples' Animals \\
Pollution & Speeding \\
Official Stamp Forgery & Employee Abuse \\
Kidnapping & President Abuse \\
\hline
\end{tabular}


Table 2. Examples of the Classification of VictimlVictimless Crimes

\begin{tabular}{|l|l|}
\hline \multicolumn{1}{|c|}{ Serious Crimes } & \multicolumn{1}{c|}{ Non-serious Crimes } \\
\hline Rape Victim & \multicolumn{1}{c|}{ (A2)Victim } \\
Financial Fraud & Pick-pocketing \\
Murder & Sexual Harassment \\
Terrorism & Shop-lifting \\
Robbery with Firearms & Intentional Killing Peoples' Animals \\
Robbery without Firearms & Employee Abuse \\
Arson & President Abuse \\
\cline { 2 - 2 } Pollution & \multicolumn{1}{|c|}{ (B2)Victimless } \\
\cline { 2 - 2 } Kidnapping & Understatement of Taxable Income \\
\hline \multicolumn{1}{|c|}{ (B1) Victimless } & Overstatement of Tax Deductions \\
\hline Bribery & Employing Illegal Worker \\
Drug Traffickingldealing & Prostitution \\
Adultery & Fail to submit a Tax Return \\
Homosexuality & Illegal Gambling \\
Islamic Abuse & Alcohol Drinking $\backslash$ dealing \\
Official Document Forgery & Begging \\
Currency Forgery & Fireworks Acquiringldealing \\
Official Seal Forgery & Running a Red Light \\
Official Stamp Forgery & Speeding \\
\hline
\end{tabular}

Table 3. Classification of Crimes into Six Groups

\begin{tabular}{|l|l|l|}
\hline \multicolumn{1}{|c|}{ Drug Related Crimes } & \multicolumn{1}{c|}{ Violent Crimes } & \multicolumn{1}{c|}{ Commercial Crimes } \\
\hline Drug Traffickingldealing & Rape & Understatement of Taxable Income \\
Alcohol Drinkingldealing & Murder & Financial Fraud \\
\hline \multicolumn{1}{|c|}{ Other Offences } & Terrorism & Official Document Forgery \\
Currency Forgery \\
Islamic Abuse & Robbery with Firearms & Official Seal Forgery \\
Employing Illegal Worker & Kidnapping & Official Stamp Forgery \\
Prostitution & Sexual Harassment & Overstatement of Tax Deductions \\
Illegal Gambling & Employee Abuse & Fail to submit a Tax Return \\
Fireworks Acquiringldealing & President Abuse & Bribery \\
\cline { 2 - 3 } Adultery & \multicolumn{1}{|c|}{ Property Crimes } & Traffic Offences \\
\cline { 2 - 3 } Homosexuality & Arson & Speeding \\
Pollution & Robbery without Firearms & Running a Red Light \\
\hline Hiding a person escaping from doing the & Intentional Killing Peoples' & Shop-lifting \\
Military service & Pick-pocketing & \\
\hline
\end{tabular}

Table 4. Crime Statistics in Yemen

\begin{tabular}{|l|c|c|}
\hline \multicolumn{1}{|c|}{ Item } & $\mathbf{2 0 0 3}$ & $\mathbf{2 0 0 4}$ \\
\hline Total Registered Crimes & 22960 & 24406 \\
\hline Total Registered Crimes Against Individuals & 10181 & 10269 \\
\hline Total Registered Assault Crimes Against Private and Personal Property & 7316 & 6773 \\
\hline Total Registered indecency Crimes & 2652 & 2394 \\
\hline Total Registered Crimes of Falsification.\& Forgery & 226 & 186 \\
\hline Total Crimes of Public Service Violations. & 159 & 867 \\
\hline Total Assault, Against Public Property & 250 & 1346 \\
\hline Total Crimes Against Public Security. & 2088 & 2512 \\
\hline Total Registered Narcotics Crimes & 88 & 59 \\
\hline Total Registered Accused people & 30575 & 25865 \\
\hline
\end{tabular}


Table 5. Profile of Respondents

\begin{tabular}{|c|c|c|}
\hline Demographic Variables & $\begin{array}{c}\text { Frequency } \\
(\mathrm{n}=\mathbf{3 3 5})\end{array}$ & Percent \% \\
\hline \multicolumn{3}{|l|}{ Gender } \\
\hline Male & 229 & 68 \\
\hline Female & 106 & 32 \\
\hline \multicolumn{3}{|l|}{ Age (years) } \\
\hline $18-29$ & 91 & 27.2 \\
\hline $30-49$ & 209 & 62.4 \\
\hline 50 and above & 35 & 10.4 \\
\hline \multicolumn{3}{|l|}{ Marital Status } \\
\hline Single & 77 & 23 \\
\hline Married & 246 & 73.4 \\
\hline Other & 12 & 3.6 \\
\hline \multicolumn{3}{|l|}{ Education } \\
\hline Before high school & 47 & 14 \\
\hline High school & 71 & 21.2 \\
\hline Higher diploma & 65 & 19.4 \\
\hline Bachelor degree & 140 & 41.8 \\
\hline Postgraduate (master \& PhD) & 12 & 3.6 \\
\hline \multicolumn{3}{|l|}{ Source of income } \\
\hline Private income source & 86 & 25.7 \\
\hline Governmental income source & 188 & 56.1 \\
\hline Owning business or self-employed source of income & 24 & 7.2 \\
\hline Other source of income & 37 & 11 \\
\hline \multicolumn{3}{|l|}{ Occupation } \\
\hline Private sector employee & 86 & 25.7 \\
\hline Governmental sector employee & 188 & 56.1 \\
\hline Businessmen or self-employed individuals & 24 & 7.2 \\
\hline Others & 37 & 11 \\
\hline \multicolumn{3}{|l|}{ Level of income } \\
\hline 240000 and below & 112 & 33.4 \\
\hline $240001-500000$ & 135 & 40.3 \\
\hline $500001-1000000$ & 58 & 17.3 \\
\hline $1000001-2000000$ & 12 & 3.6 \\
\hline $200001-5000000$ & 0 & 0 \\
\hline 5000000 and above & 18 & 5.4 \\
\hline \multicolumn{3}{|l|}{ Tax return preparer } \\
\hline Yourself & 18 & 5.4 \\
\hline Assistant by a friend, a spouse or a relative & 31 & 9.3 \\
\hline Tax agent & 68 & 20.3 \\
\hline Others & 218 & 65.1 \\
\hline
\end{tabular}


Table 6. Mean Scores and Rank of Offences

\begin{tabular}{|c|c|c|c|c|c|}
\hline \multicolumn{3}{|l|}{ Offences } & Mean & SD & Rank \\
\hline \multicolumn{3}{|l|}{ Islamic abuse } & 4.86 & .517 & 1 \\
\hline \multicolumn{3}{|l|}{ Murder } & 4.77 & .70774 & 2 \\
\hline \multicolumn{3}{|l|}{ Drug trafficking $\backslash$ dealing } & 4.45 & .73214 & 3 \\
\hline \multicolumn{3}{|l|}{ Adultery } & 4.41 & .75219 & 4 \\
\hline \multicolumn{3}{|l|}{ Prostitution } & 4.37 & .74592 & 5 \\
\hline \multicolumn{3}{|l|}{ Kidnapping } & 4.32 & 2.189 & 6 \\
\hline \multicolumn{3}{|l|}{ Rape } & 4.29 & .961 & 7 \\
\hline \multicolumn{3}{|l|}{ Robbery with firearms } & 4.26 & .766 & 8 \\
\hline \multicolumn{3}{|l|}{ Terrorism } & 4.14 & 1.02613 & 9 \\
\hline \multicolumn{3}{|l|}{ Alcohol drinking \dealing } & 4.12 & .96101 & 10 \\
\hline \multicolumn{3}{|l|}{ Arson } & 4.05 & .789 & 11 \\
\hline \multicolumn{3}{|l|}{ Bribery } & 3.92 & 1.081 & 12 \\
\hline \multicolumn{3}{|l|}{ Homosexuality } & 3.90 & 1.019 & 13 \\
\hline \multicolumn{3}{|l|}{ Official seal forgery } & 3.88 & .943 & 14 \\
\hline \multicolumn{3}{|l|}{ Currency forgery } & 3.80 & .974 & 15 \\
\hline \multicolumn{3}{|l|}{ Financial fraud } & 3.77 & .83837 & 16 \\
\hline \multicolumn{3}{|l|}{ Official document forgery } & 3.76 & .757 & 17 \\
\hline \multicolumn{3}{|l|}{ Illegal gambling } & 3.61 & 1.05250 & 18 \\
\hline \multicolumn{3}{|l|}{ Pollution } & 3.59 & 1.057 & 19 \\
\hline \multicolumn{3}{|l|}{ Shop- lifting } & 3.57 & 1.00015 & 20 \\
\hline \multicolumn{3}{|l|}{ Sexual harassment } & 3.51 & 1.11292 & 21 \\
\hline \multicolumn{3}{|l|}{ Pick- pocketing } & 3.15 & 1.07675 & 22 \\
\hline \multicolumn{3}{|l|}{ Robbery without firearms } & 3.10 & .995 & 23 \\
\hline \multicolumn{3}{|l|}{ Employing illegal worker } & 3.07 & 1.01653 & 24 \\
\hline \multicolumn{3}{|l|}{ Official stamps forgery } & 2.81 & 1.063 & 25 \\
\hline \multicolumn{3}{|l|}{ Fireworks acquiringldealing } & 2.77 & .952 & 26 \\
\hline Begging & & & 2.40 & 1.012 & 27 \\
\hline Understatement of taxable income & & & 2.39 & 1.35951 & 28 \\
\hline Overstatement of tax deductions & & & 2.078 & 1.14251 & 29 \\
\hline Fail to submit a tax return & & & 2.04 & 1.01988 & 30 \\
\hline Table 7. Category of Offences and Ra & & & & & \\
\hline Category of offences & Items & Mean & & SD & Rank \\
\hline Drug related crimes & 2 & 4.29 & & .68457 & 1 \\
\hline Violent crimes & 6 & 4.21 & & .60121 & 2 \\
\hline Other offences & 9 & 3.66 & & .46081 & 3 \\
\hline Commercial crimes & 6 & 3.65 & & .64551 & 4 \\
\hline Property crimes & 4 & 3.47 & & .75208 & 5 \\
\hline Tax evasion & 3 & 2.17 & & 1.00923 & 6 \\
\hline
\end{tabular}

Table 8. Comparison of Tax Evasion to Other Crimes Category

\begin{tabular}{|l|c|c|}
\hline \multicolumn{1}{|c|}{ Pair of Offences } & T-value & Sig \\
\hline Tax Evasion - Drug Related Crimes & 34.355 & $0.000^{*}$ \\
\hline Tax Evasion - Violent Crimes & 39.841 & $0.000^{*}$ \\
\hline Tax Evasion - Property Crimes & 22.289 & $0.000^{*}$ \\
\hline Tax Evasion - Other Crimes & 29.667 & $0.000^{*}$ \\
\hline Tax Evasion- Commercial Crimes & -30.052 & $0.000^{*}$ \\
\hline
\end{tabular}

Significant at 0.05 level 